\title{
PENGARUH EDUKASI GIZI MENGGUNAKAN LEAFLET KEMENKES TERHADAP PERILAKU KONSUMSI SAYUR DAN BUAH PADA REMAJA DI SMA NEGERI 10 MAKASSAR
}

\section{THE EFFECT OF NUTRITION EDUCATION USING KEMENKES' LEAFLET TO ADOLECENCE'S FRUIT AND VEGETABLE COMSUPTION BEHAVIOR IN SMA NEGERI 10 MAKASSAR}

\author{
Herman $^{1}$, Citrakesumasari ${ }^{1}$, Healthy Hidayanti ${ }^{1}$, Nurhaedar Jafar ${ }^{1}$, Devintha Virani ${ }^{1}$ \\ (hermangizi14@gmail.com/085299139813) \\ ${ }^{1}$ Program Studi Ilmu Gizi, Fakultas Kesehatan Masyarakat, Universitas Hasanuddin, Makassar
}

\begin{abstract}
ABSTRAK
Latar Belakang: Rendahnya konsumsi buah dan sayur pada remaja dapat berisiko dalam memicu perkembangan penyakit degeneratif seperti obesitas, diabetes, hipertensi, dan kanker pada tahapan kehidupan selanjutnya. Tujuan: Penelitian ini bertujuan untuk mengetahui pengaruh pemberian edukasi gizi menggunakan leaflet terhadap pengetahuan, sikap, dan pola konsumsi sayur dan buah pada remaja di SMAN 10 Makassar tahun 2018. Bahan dan Metode: Jenis penelian ini adalah quasi experiment dengan desain penelitian one group pre-test post-test. Sampel penelitian sebesar 43 siswa kelas XI dan XII yang dipilih secara proportional random sampling. Pengetahuan dan sikap responden diukur menggunakan kuesioner dan leaflet. Pola konsumsi sayur dan buah responden diukur dengan menggunakan Food Frequency Questionnaire $(F F Q)$. Data dianalisis dengan uji Mc Nemar. Hasil: Hasil penelitian menunjukkan bahwa tidak ada perbedaan pengetahuan $(\mathrm{p}=0,774)$, sikap $(\mathrm{p}=0,500)$, frekuensi konsumsi sayur $(\mathrm{p}=1,000)$, porsi konsumsi sayur $(\mathrm{p}=1,000)$, frekuensi konsumsi buah $(\mathrm{p}=0,815)$, dan porsi konsumsi buah $(\mathrm{p}=1,000)$ sebelum dan sesudah edukasi menggunakan leaflet. Kesimpulan: Tidak terdapat pengaruh leaflet terhadap pengetahuan, sikap, dan pola konsumsi sayur dan buah pada remaja di SMAN 10 Makassar.
\end{abstract}

\section{Kata kunci: leaflet, pengetahuan, sikap, konsumsi buah dan sayur}

\begin{abstract}
Background: Lack of fruit and vegetable consumptions among adolescents can be high risk to suffer degenerative diseases such as obesity, diabetes, hypertension, and cancer for the future life. Objective: This study aims to investigate the effect of nutrition education using leaflet towards knowledge, attitude, and fruit and vegetable consumption patterns in adolescents in SMAN 10 MAKASSAR in 2018. Ingredients and Methods: Design of this study is quasi experiment using one group pre-and post-test. 43 students are involved as samples who are in XI and XII classes at SMAN 10 Makassar selected by using proportional random sampling. The pattern of fruit and vegetable consumptions were measured with Food Frequency Questionnaire
\end{abstract}


$(F F Q)$. All of data were analyzed using Mc-Nemar test. Result: The finding of this study shows that there were no difference on knowledge $(p=0.774)$, attitude $(p=0.500)$, the frequency of vegetable $(p=1,000)$, the portion of vegetable consumption $(p=1.000)$, the frequency of fruit consumption $(p=0.185)$, and the portion of fruit consumption $(p=1.000)$ before and after education using leaflet. There was no effect of leaflet towards knowledge, attitude, and fruit and vegetable consumption among adolescents in SMAN 10 Makassar.

Conclusion: It needs more effort to enhance the consumption of fruit and vegetable among adolescents.

Keywords: leaflet, knowledge, attitude, fruit and vegetable consumptions.

\section{PENDAHULUAN}

Kecepatan pertumbuhan dan perkembangan pada masa remaja merupakan proses tercepat kedua setelah masa pertumbuhan dan perkembangan bayi. Oleh karena itu, asupan gizi yang optimal sangat diperlukan untuk menjamin pertumbuhan dan perkembangan yang normal pada remaja yang akan berdampak pada masa sekarang maupun masa yang akan datang. ${ }^{1}$ Salah satu masalah umum dari perilaku konsumsi remaja adalah kurangnya konsumsi buah dan sayur. Zatzat gizi yang diperlukan pada masa remaja diantaranya protein, kalsium, seng, zat besi, vitamin dan serat. Selain pemenuhan zat gizi makro, juga diperlukan zat gizi mikro untuk remaja terutama asupan serat dan vitamin. Faktor yang dapat berpengaruh terhadap asupan gizi remaja adalah lingkungan seperti keluarga, sekolah dan teman sebaya (peer group). ${ }^{2}$

Rekomendasi kecukupan konsumsi buah dan sayur menurut WHO 2003 yaitu sebanyak 400 gram per hari atau sebanyak 3-5 porsi sehari. ${ }^{3}$ Selain itu, dalam Dietary Guidelines for American dikatakan bahwa rekomendasi minimal buah adalah $2 \mathrm{kali} / \mathrm{hari}$ dan $3 \mathrm{kali} / \mathrm{hari}$ untuk konsumsi sayur atau setara dengan konsumsi buah dan sayur 5 kali/hari. ${ }^{3}$ Berbagai penelitian menyebutkan kebanyakan remaja tidak dapat memenuhi rekomendasi tersebut. ${ }^{3}$ Menurut data Riskesdas tahun 2007 hingga 2013 menunjukkan bahwa di Indonesia tidak terjadi perubahan yang berarti 93,6\% menjadi 93,5\%. Data dari Riskesdas 2013 ditemukan bahwa perubahan yang paling menonjol terjadi di Gorontalo, dengan proporsi kurang konsumsi sayur dan buah semakin meningkat dari 83,5\% menjadi 92,5\%, demikian juga dengan Provinsi Sulawesi Selatan yang mengalami peningkatan dari $93,7 \%$ menjadi sekitar $96 \%{ }^{4}$

Proporsi kurang konsumsi sayur dan buah pada remaja di Kota Makassar masih tergolong tinggi. Hal ini dibuktikan pada penelitian Achmad, menunjukkan hasil bahwa dari 308 responden yang memiliki konsumsi sayur dan buah kategori kurang yaitu SMAN 16 Makassar sebanyak 97,3\% dan SMAN 10 Makassar sebanyak 97,5\%. Responden di SMAN 16 yang berpengetahuan baik sebanyak 63,1\% sedangkan responden dari SMAN 10 makassar yang berpengetahuan kurang sebanyak 58,5\%. Responden yang memiliki sikap positif di SMAN 16 Makassar sebanyak 55\% sedangkan di SMAN 10 Makassar yang memiliki sikap negatif sebanyak 52,8\%. ${ }^{5}$

Kurangnya konsumsi buah dan sayur dapat menyebabkan penyakit degeneratif seperti obesitas, diabetes, hipertensi, tekanan darah tinggi, dan kanker. Kematian dini dan kehidupan 
produktif yang hilang karena cacat, 28\% dari kematian di seluruh dunia disebabkan karena rendahnya konsumsi buah dan sayur. Selain itu, tidak cukup buah dan sayur diperkirakan menyebabkan sekitar 14\% dari kematian akibat kanker pencernaan, sekitar $11 \%$ dari jantung dan sekitar 9\% kematian stroke. ${ }^{6}$ Selain itu, kurangnya konsumsi buah dan sayur dapat mengakibatkan berbagai dampak yaitu menurunnya imunitas/kekebalan tubuh seperti mudah terkena flu, mudah mengalami stres atau depresi, tekanan darah tinggi, gangguan pencernaan seperti sembelit, gusi berdarah, sariawan, gangguan mata, kulit keriput, arthritis, osteoporosis, jerawat, kelebihan kolesterol darah, dan kanker. ${ }^{7}$

Pendidikan gizi adalah suatu upaya untuk mengadakan perubahan pengetahuan, sikap maupun keterampilan atau praktek dalam hal konsumsi makanan. Pendidikan gizi sangat penting karena meskipun daya beli masyarakat tinggi dan pangan tersedia namun apabila pengetahuan gizi masyarakat kurang baik maka masyarakat tidak dapat memenuhi kebutuhan gizi. ${ }^{8}$ Proses edukasi gizi tidak terlepas dari pengaruh penggunaan alat peraga atau media yang mampu mendukung berlangsungnya kegiatan edukasi tersebut. ${ }^{9}$ Pemilihan leaflet sebagai media edukasi karena media tersebut bersifat visual. Panca indera yang paling banyak menyalurkan pengetahuan ke otak adalah mata (kurang lebih 75\% sampai 87\%), sedangkan 13\% sampai 25\%, pengetahuan manusia diperoleh dan disalurkan melalui panca indera yang lain. ${ }^{10}$

Intervensi dengan pemberian leaflet makanan sehat pada remaja kelas khusus di SMA Negeri 1 Panyabungan Kabupaten Mandailing Natal mampu meningkatkan perilaku (pengetahuan, sikap, dan tindakan) konsumsi makanan jajanan pada siswa sekolah menengah umum tentang makanan jajanan. ${ }^{11}$ Selain itu, berdasarkan uji statistik ditemukan bahwa ada perbedaan yang signifikan pada pengetahuan, konsumsi buah dan sayur responden sebelum dan sesudah edukasi melalui media leaflet terhadap perubahan konsumsi buah dan sayur pada siswa SMP Al Chasanah. ${ }^{12}$

Berdasarkan uraian tersebut, perlu dilakukan intervensi pendidikan gizi untuk memberikan informasi mengenai pentingnya sayur dan buah yang diharapkan dapat berdampak pada perubahan pengetahuan, sikap, dan tindakan konsumsi sayur dan buah pada remaja. Penelitian ini bertujuan untuk mengetahui pengaruh pemberian edukasi gizi menggunakan leaflet KEMENKES terhadap pengetahuan, sikap, dan pola konsumsi sayur dan buah pada remaja.

\section{BAHAN DAN METODE}

Penelitian ini adalah quasy experiment dengan desain penelitian one group pre-test posttest. Penelitian ini dilaksanakan pada bulan Oktober-November 2018 di SMAN 10 Kota Makassar. Penelitian dilakukan pada siswa kelas XI dan XII dengan populasi 697 siswa. Besar sampel minimum dalam penelitian ini dihitung menggunakan rumus besar sampel menurut Snedecor G.W \& Cochran dan Lameshow sehingga diperoleh sebanyak 36 sampel. ${ }^{13}$ Untuk mengindari adanya drop out atau missing maka ditambahkan $20 \%$ sehingga jumlah sampelnya menjadi 43 siswa. Pengambilan sampel dalam penelitian ini dengan teknik probability sample dengan menggunakan proportional random sampling. ${ }^{14}$

Penelitian ini dilakukan selama 14 hari dengan penyampaian materi sebanyak 14 kali selama kurang lebih 30 menit. Pada hari pertama, peneliti terlebih dahulu melakukan pengukuran 
antropometri yang terdiri atas pengukuran berat badan dan tinggi badan untuk mengetahui karakteristik responden berdasarakan status gizinya. Setelah itu responden diberi penjelasan tentang pelaksanaan penelitian kemudian mereka diberi surat kesediaan untuk mengikuti penelitian ini. Siswa yang bersedia mengikuti penelitian kemudian diminta untuk mengisi kuesioner pre-test, dan setelah itu dilakukan wawancara FFQ semi kuantitatif. Kemudian dilanjutkan dengan penyuluhan tentang pentingnya mengonsumsi sayur dan buah menggunakan media leaflet. Setelah 7 hari, dilakukan pertemuan kembali untuk merefresh materi edukasi. Pelaksanaan post-test dilakukan seminggu setelah pertemuan terakhir dengan tujuan untuk memastikan bahwa materi yang telah disampaikan mampu dipahami dan diingat oleh responden dengan mengisi kuesioner post-test serta dilakukan kembali wawancara FFQ semi kuantitatif untuk mengetahui perubahan pola konsumsi sayur dan buah responden.

Instrumen yang digunakan pada penelitian ini adalah kuesioner data responden, kuesioner pengetahuan dan sikap, FFQ semi kuantitatif, foto makanan (food picture), serta leaflet buah dan sayur yang digunakan sebagai media edukasi. Leaflet buah dan sayur Kemenkes merupakan media cetak yang berisi penjelasan dalam bentuk tulisan dan gambar tentang kandungan gizi dan manfaaat buah dan sayur, dampak kurang konsumsi buah dan sayur, serta anjuran kecukupan konsumsi buah dan sayur.

Metode pengumpulan data karakteristik responden, pengetahuan, serta sikap diperoleh melalui kuesioner, sedangkan data konsumsi sayur dan buah dikumpulkan dengan menggunakan lembar FFQ-SQ yang diisi dengan metode wawancara oleh peneliti. Kemudian data sekunder meliputi data umum sekolah seperti jumlah siswa dan yang terkait atau mendukung penelitian diperoleh dari profil sekolah dan wawancara dengan staff bagian administrasi sekolah.

Kuesioner yang digunakan untuk mengetahui tingkat pengetahuan siswa berisi 10 soal dengan nilai 1 untuk jawaban benar dan 0 untuk jawaban salah, sedangkan kuesioner sikap dinilai menggunakan skala lickert 1-4 melaui 5 pernyataan negatif dan 5 pernyataan positif. Skor yang diperoleh dari jumlah jawaban siswa dikategorikan berdasarkan mean hipotetik dengan kategori cukup kurang dan positif negatif. Data tentang konsumsi sayur dan buah di dapat dengan cara menilai pola konsumsi responden dengan menggunakan form SQFFQ (Semi Quantitative Food Frequency Questionnaire). Tingkat konsumsi sayur dan buah diukur dengan menilai konsumsi sayur dan buah secara terpisah. Kategori konsumsi sayur dan buah berdasarkan pedoman gizi seimbang. Untuk porsi konsumsi sayur, $\geq 250 \mathrm{~g}$ per orang/hari termasuk kategori cukup, dan $<250$ g per orang/hari kategori kurang. Sedangkan frekuensi sayur, cukup jika konsumsi sayur $\geq 1$ kali per hari, dan kurang jika konsumsi sayur $<1$ kali per hari. Demikian pula dengan porsi konsumsi buah, $\geq 150$ g per orang/hari termasuk kategori cukup, dan $<150$ g per orang/hari kategori kurang. Sedangkan frekuensi buah, cukup jika konsumsi buah $\geq 1$ kali per hari, dan kurang jika konsumsi buah $<1$ kali per hari. ${ }^{15,16}$

Analisis data statistik yang digunakan pada penelitian ini adalah uji Mc Nemar $(p<0,05)$ untuk mengetahui kemaknaan perubahan pengetahuan, sikap, tindakan mengenai konsumsi sayur dan buah sebelum dan sesudah dilakukan edukasi gizi melalui leaflet. Penelitian ini telah 
memperoleh persetujuan dari komisi etik FKM Universitas Hasanuddin dengan nomor 1647/UN4.14.7.1/TP.01.02/2020.

\section{HASIL}

Karakteristik responden yang diteliti pada penelitian ini adalah umur, jenis kelamin, pekerjaan orang tua, dan pendidikan ibu. Karakteristik umur dan jenis kelamin sangat berpengaruh dengan kemampuan responden dalam menyerap materi yang disampaikan, sedangkan karakteristik pekerjaan orang tua dan pendidikan ibu berpengaruh terhadap pola konsumsi sayur dan buah remaja. Karakteristik responden dapat dilihat pada Tabel 1.

Tabel 1. Distribusi Karakteristik Responden di SMAN 10 Makassar Tahun 2018

\begin{tabular}{|c|c|c|}
\hline Karakteristik Responden & $\mathbf{n}$ & $\%$ \\
\hline \multicolumn{3}{|l|}{ Jenis Kelamin } \\
\hline Laki-laki & 17 & 39,5 \\
\hline Perempuan & 26 & 60,5 \\
\hline \multicolumn{3}{|l|}{ Umur } \\
\hline 14 tahun & 0 & 0 \\
\hline 15 tahun & 5 & 11,6 \\
\hline 16 tahun & 20 & 46,5 \\
\hline 17 tahun & 18 & 41,9 \\
\hline \multicolumn{3}{|l|}{ Pekerjaan Ayah } \\
\hline PNS & 4 & 9,3 \\
\hline TNI/POLRI & 2 & 4,7 \\
\hline Swasta & 5 & 11,6 \\
\hline Wiraswasta & 10 & 23,3 \\
\hline Buruh/Petani & 13 & 30,2 \\
\hline Lainnya & 9 & 20,9 \\
\hline \multicolumn{3}{|l|}{ Pekerjaan Ibu } \\
\hline PNS & 3 & 7,0 \\
\hline TNI/POLRI & 0 & 0 \\
\hline Swasta & 0 & 0 \\
\hline Wiraswasta & 2 & 4,7 \\
\hline Buruh/Petani & 0 & 0 \\
\hline IRT & 36 & 83,7 \\
\hline Lainnya & 2 & 4,7 \\
\hline \multicolumn{3}{|l|}{ Pendidikan Ibu } \\
\hline Tidak Sekolah & 3 & 7,0 \\
\hline SD & 4 & 9,3 \\
\hline SMP/sederajat & 8 & 18,6 \\
\hline SMA/sederajat & 20 & 46,5 \\
\hline Diploma & 3 & 7,0 \\
\hline Sarjana S1/S2/S3 & 5 & 11,6 \\
\hline Total & 43 & 100 \\
\hline
\end{tabular}

Sumber: Data Primer, 2018

Tabel 1 menunjukkan bahwa lebih banyak responden berjenis kelamin perempuan $(60,5 \%)$ daripada laki-laki (39,5\%). Sebagian besar responden berumur 16 tahun, yakni sebesar 
46,5\% dan paling sedikit 11,6\% responden berumur 15 tahun. Mayoritas ayah responden bekerja sebagai buruh/petani (30,2\%) sedangkan ibu responden mayoritas tidak bekerja atau ibu rumah tangga $(83,7 \%)$. Mayoritas ibu responden penelitian berpendidikan tamat SMA dengan persentase sebesar $46,5 \%$.

Tabel 2. Distribusi Pengetahuan, Sikap, Konsumsi Sayur, dan Konsumsi Buah Remaja Sebelum dan Sesudah Edukasi Gizi di SMAN 10 Makassar Tahun 2018

\begin{tabular}{|c|c|c|c|c|}
\hline \multirow{2}{*}{ Variabel } & \multicolumn{2}{|c|}{ Sebelum } & \multicolumn{2}{|c|}{ Sesudah } \\
\hline & $\mathbf{n}$ & $\%$ & $\bar{n}$ & $\%$ \\
\hline \multicolumn{5}{|l|}{ Pengetahuan } \\
\hline Cukup & 28 & 65,1 & 30 & 69,8 \\
\hline Kurang & 15 & 34,9 & 13 & 30,2 \\
\hline \multicolumn{5}{|l|}{ Sikap } \\
\hline Positif & 41 & 95,3 & 43 & 100 \\
\hline Negatif & 2 & 4,7 & 0 & 0 \\
\hline \multicolumn{5}{|l|}{ Konsumsi Sayur } \\
\hline \multicolumn{5}{|l|}{ Frekuensi } \\
\hline Cukup & 5 & 11,6 & 5 & 11,6 \\
\hline Kurang & 38 & 88,4 & 38 & 88,4 \\
\hline \multicolumn{5}{|l|}{ Porsi } \\
\hline Cukup & 17 & 39,5 & 17 & 39,5 \\
\hline Kurang & 26 & 60,5 & 26 & 60,5 \\
\hline \multicolumn{5}{|l|}{ Konsumsi Buah } \\
\hline \multicolumn{5}{|l|}{ Frekuensi } \\
\hline Cukup & 0 & 0 & 0 & 0 \\
\hline Kurang & 43 & 100 & 43 & 100 \\
\hline \multicolumn{5}{|l|}{ Porsi } \\
\hline Cukup & 32 & 74,4 & 33 & 76,7 \\
\hline Kurang & 11 & 25,6 & 10 & 23,3 \\
\hline Total & 43 & 100 & 43 & 100 \\
\hline
\end{tabular}

Sumber: Data Primer, 2018

Perbedaan tingkat pengetahuan, sikap, konsumsi sayur, dan konsumsi buah responden dapat dilihat pada Tabel 2 distribusi pengetahuan, sikap, konsumsi sayur, dan konsumsi buah remaja sebelum dan sesudah edukasi gizi di SMAN 10 Makassar tahun 2018. Tingkat pengetahuan siswa sebelum diberi intervensi memiliki tingkat pengetahuan yang cukup $65,1 \%$ dan pengetahuan kurang 34,9\%. Setelah diberi edukasi gizi menggunakan leaflet, persentase yang memiliki tingkat pengetahuan cukup meningkat menjadi 69,8\% dan pengetahuan kurang menurun menjadi $30,2 \%$.

Tabel 2 distribusi pengetahuan, sikap, konsumsi sayur, dan konsumsi buah remaja sebelum dan sesudah edukasi gizi di SMAN 10 Makassar tahun 2018 menunjukkan tingkat sikap sebelum diberi intervensi memiliki sikap positif $95,3 \%$ dan sikap negatif $4,7 \%$. Setelah diberi 
edukasi gizi menggunakan leaflet, terjadi peningkatan nilai post-test yang menunjukkan bahwa semua responden tergolong dalam sikap positif.

Tabel 2 distribusi pengetahuan, sikap, konsumsi sayur, dan konsumsi buah remaja sebelum dan sesudah edukasi gizi di SMAN 10 Makassar tahun 2018 menunjukkan tingkat konsumsi sayur sebelum diberi intervensi memiliki frekuensi konsumsi sayur cukup 11,6\% dan frekuensi sayur kurang 88,4\%. Sedangkan porsi konsumsi sayur cukup 39,5\% dan porsi konsumsi sayur kurang 60,5\%. Setelah diberi edukasi gizi menggunakan leaflet, tidak terjadi perubahan frekuensi maupun porsi konsumsi sayur.

Tabel 3. Rangkuman Hasil Analisis Bivariat Menggunakan Uji Mc Nemar

\begin{tabular}{ll}
\hline Variabel & P value \\
\hline Pengetahuan Sebelum dan Sesudah Edukasi Menggunakan Leaflet & 0,774 \\
Sikap Sebelum dan Sesudah Edukasi Menggunakan Leaflet & 0,500 \\
Frekuensi Konsumsi Sayur Sebelum dan Sesudah Edukasi Menggunakan Leaflet & 1,000 \\
Porsi Konsumsi Sayur Sebelum dan Sesudah Edukasi Menggunakan Leaflet & 1,000 \\
Frekuensi Konsumsi Buah Sebelum dan Sesudah Edukasi Menggunakan Leaflet & 0,815 \\
Porsi Konsumsi Buah Sebelum dan Sesudah Edukasi Menggunakan Leaflet & 1,000
\end{tabular}

Sumber: Data Primer, 2018

Tabel distribusi pengetahuan, sikap, konsumsi sayur, dan konsumsi buah remaja sebelum dan sesudah edukasi gizi di SMAN 10 Makassar tahun 2018 menunjukkan tingkat konsumsi buah sebelum diberi intervensi memiliki frekuensi konsumsi buah kurang $100 \%$. Sedangkan porsi konsumsi sayur cukup 74,4\% dan porsi konsumsi sayur kurang 25,6\%. Setelah diberi edukasi gizi menggunakan leaflet, tidak terjadi perubahan frekuensi konsumsi sayur, sedangkan porsi konsumsi buah cukup meningkat menjadi 76,7\% dan porsi konsumsi buah kurang menurun menjadi $23,3 \%$.

Tabel 3 rangkuman hasil analisis bivariat menggunakan Uji Mc Nemar menunjukkan hasil uji statistik menggunakan Mc Nemar diperoleh nilai signifikansi pengetahuan $(\mathrm{p}=0,774)$, sikap $(p=0,500)$, frekuensi konsumsi sayur $(p=1,000)$, porsi konsumsi sayur $(p=1,000)$, frekuensi konsumsi buah $(\mathrm{p}=0,815)$, dan porsi konsumsi buah $(\mathrm{p}=1,000)$ di mana angka ini melebihi 0,05 , yang artinya tidak terdapat perbedaan pengetahuan, sikap, dan pola konsumsi sayur dan buah pada remaja sebelum dan setelah diberikan edukasi menggunakan media leaflet.

\section{PEMBAHASAN}

Masa remaja (adolescence) merupakan masa terjadinya perubahan yang berlangsung cepat dalam hal pertumbuhan fisik, kognitif, dan psikososial. Masa ini merupakan masa peralihan dari anak-anak menuju remaja yang ditandai dengan banyak perubahan, di antaranya pertambahan massa otot, jaringan lemak tubuh, dan perubahan hormon. Perubahan tersebut memengaruhi kebutuhan gizi. Selain itu, kebutuhan gizi pada remaja juga dipengaruhi oleh faktor psikologis dan sosial. ${ }^{17}$

Pengetahuan adalah hasil dari tahu, yang akan terjadi setelah seseorang melakukan penginderaan terhadap suatu objek tertentu, seperti melihat, mendengar, mencium, merasa, dan juga meraba. Namun, sebagian besar pengetahuan itu sendiri diperoleh melalui mata dan telinga. 
Jadi, dengan kata lain dari hasil mendengar dan juga melihat. ${ }^{18}$ Salah satu strategi untuk memperoleh perubahan perilaku menurut WHO adalah dengan pemberian informasi untuk meningkatkan pengetahuan sehingga menimbulkan kesadaran dan pada akhirnya orang akan berperilaku sesuai dengan pengetahuannya tersebut. ${ }^{18}$

Berdasarkan hasil analisis dengan menggunakan uji McNemar menunjukkan tidak terdapat perbedaan pengetahuan remaja antara sebelum dan sesudah pemberian leaflet, di mana diperoleh nilai probabilitas $(p)=0,774(p>0,05)$, atau dengan perkataan lain tidak ada perbedaan secara signifikan antara pengetahuan responden sebelum dan sesudah pemberian leaflet.

Meskipun hasilnya tidak memberikan efek, tetapi berdasarkan analisis univariat, persentase remaja yang memiliki pengetahuan cukup pada saat pre-test sebanyak 65,1\% kemudian mengalami peningkatan pada saat post-test menjadi 69,8\%. Peningkatan ini dapat dilihat dari item per soal berdasarkan persentase jawaban benar. Dari 10 pertanyaan pengetahuan, ada 6 pertanyaan yang meningkat sebelum maupun sesudah intervensi, dan ada 3 pertanyaan yang menurun selebihnya pertanyaan tersebut tidak mengalami perubahan.

Hasil penelitian ini sejalan dengan penelitian yang dilakukan oleh Saputra tentang pengaruh pemberian edukasi gizi melalui media video dan leaflet terhadap perubahan konsumsi buah dan sayur pada siswa SMP Al Chasanah yang menunjukkan hasil bahwa tidak ada perbedaan pengetahuan antara siswa sebelum diberi edukasi melalui media video dan media leaflet pada siswa SMP Al Chasanah. ${ }^{12}$ Hasil penelitian ini berbeda dari hasil penelitian Tampubolon tentang pengaruh media visual poster dan leaflet makanan sehat terhadap perilaku konsumsi makanan jajanan pelajar kelas khusus SMA Negeri 1 Panyabungan Kabupaten Mandailing Natal menunjukkan bahwa pemajangan poster dan pemberian leaflet dapat meningkatkan pengetahuan pelajar kelas khusus. ${ }^{11}$

Sikap merupakan respon tertutup seseorang terhadap stimulus atau objek tertentu dengan melibatkan faktor pendapat dan emosi sehingga menghasilkan pemikiran suka-tidak suka, setujutidak setuju, baik-tidak baik, dan sebagainya. Sikap seseorang menunjukkan suatu kesiapan atau ketersediaan untuk bertindak namun belum menunjukkan suatu tindakan yang nyata, sikap hanya bagian dari faktor predisposisi suatu perilaku. ${ }^{19}$

Berdasarkan hasil analisis dengan menggunakan uji McNemar menunjukkan tidak terdapat perbedaan sikap remaja antara sebelum dan sesudah pemberian leaflet, di mana diperoleh nilai probabilitas $(p)=0,500(p>0,05)$, atau dengan perkataan lain tidak ada perbedaan secara signifikan antara sikap remaja sebelum dan sesudah pemberian leaflet. Hal ini menunjukkan bahwa pemberian leaflet tidak mampu memengaruhi sikap siswa tentang pentingnya sayur dan buah.

Berdasarkan analisis univariat, persentase remaja yang memiliki sikap positif pada saat pre-test sebanyak 95,3\% kemudian mengalami peningkatan pada saat post-test menjadi 100\% di mana semua remaja memiliki sikap yang positif. Peningkatan ini dapat dilihat dari item per soal yang mengalami peningkatan jumlah jawaban benar. Dari 10 soal pernyataan sikap, ada 5 pernyataan yang meningkat sebelum maupun sesudah intervensi, dan ada 3 pernyataan yang menurun selebihnya pernyataan tersebut tidak mengalami perubahan. 
Hal ini sejalan dengan penelitian yang dilakukan Azzahra tentang pengaruh konseling terhadap pengetahuan dan sikap pemberian MP-ASI dapat diketahui bahwa tidak terjadi peningkatan sikap pada kelompok kontrol. Hasil uji wilcoxon sign rank test menunjukkan bahwa tidak ada perbedaan sikap sebelum dan sesudah diberi leaflet. ${ }^{20}$ Hal ini tidak sejalan dengan penelitian yang dilakukan Dakhi tentang pengaruh pemberian pendidikan gizi melalui media leaflet tentang sayur dan buah terhadap pengetahuan, sikap, dan praktik ibu murid SDN 105349 Paluh Kemiri dalam menyediakan sayur dan buah untuk keluarga di mana ada peningkatan sikap sampel tentang sayur dan buah setelah diberikan pendidikan gizi melalui media leaflet. ${ }^{21}$

Terbentuknya domain suatu perilaku baru, terutama pada orang dewasa dimulai pada domain kognitif, dalam arti subyek tahu terlebih dahulu terhadap stimulasi yang berupa materi atau obyek diluarnya, sehingga menimbulkan pengetahuan baru pada subyek yang diketahui itu. Akhirnya rangsangan yakni obyek yang telah diketahui dan disadari sepenuhnya tersebut akan menimbulkan respon lebih jauh lagi, yaitu berupa tindakan (action) terhadap atau sehubungan dengan stimulasi atau obyek tadi. Namun demikian, di dalam kenyataan stimulasi yang diterima subyek dapat langsung menimbulkan tindakan. ${ }^{18}$

Berdasarkan hasil analisis dengan menggunakan uji McNemar menunjukkan tidak terdapat perbedaan frekuensi dan porsi konsumsi sayur remaja antara sebelum dan sesudah pemberian leaflet, di mana diperoleh nilai probabilitas $(p)=1,000 \quad(p>0,05)$, atau dengan perkataan lain tidak ada perbedaan secara signifikan antara frekuensi dan porsi konsumsi sayur remaja sebelum dan sesudah pemberian leaflet. Hal ini menunjukkan bahwa pemberian leaflet tidak mampu memengaruhi frekuensi dan porsi konsumsi sayur siswa.

Meskipun hasilnya tidak memberikan efek, tetapi berdasarkan analisis univariat, baik sebelum dan sesudah intervensi frekuensi konsumsi sayur yang kurang masih tinggi yaitu di atas $50 \%$, kurangnya ternyata dari semua jenis sayur-sayuran yang satu-satunya tinggi yaitu dengan skor 1,09 1x/hari hanya tomat saja selebihnya tidak. Untuk porsi konsumsi, tidak terdapat perubahan porsi konsumsi sayur remaja baik sebelum intervensi maupun setelah intervensi edukasi. Hal ini kemungkinan disebabkan karena lama pemberian intervensi edukasi terlalu singkat, sedangkan untuk mengubah kebiasaan konsumsi memerlukan waktu yang tidak singkat.

Berdasarkan hasil analisis dengan menggunakan uji McNemar menunjukkan tidak terdapat perbedaan frekuensi konsumsi buah remaja antara sebelum dan sesudah pemberian leaflet, di mana diperoleh nilai probabilitas $(p)=0,815(p>0,05)$, atau dengan perkataan lain tidak ada perbedaan secara signifikan antara frekuensi konsumsi buah remaja sebelum dan sesudah pemberian leaflet. Hal ini menunjukkan bahwa pemberian leaflet tidak mampu memengaruhi frekuensi konsumsi buah siswa.

Berdasarkan analisis univariat, diketahui bahwa hampir semua remaja bukan pemakan buah, dapat dilihat dari rata-rata frekuensi konsumsi buah remaja sebelum dan sesudah intervensi skor paling rendah yaitu 0,18 pada anggur dan 0,22 pada apel yang artinya hanya dikonsumsi 1 kali per minggu saja. Skor yang paling tinggi mengalami perubahan konsumsi jenis buah-buahan di mana sebelum intervensi skor yang paling tinggi yaitu pisang emas dengan rata-rata skor 0,44 dan sesudah intervensi yaitu mangga dengan rata-rata skor 0,83. Hal ini dapat disimpulkan, bahwa remaja tidak menyukai anggur dan apel. Ketidaksukaan pada buah tersebut terkait dengan 
ketersediaan karena buah-buah itu harganya mungkin mahal. Di mana sebagian besar pekerjaan ayah remaja bekerja sebagai buruh/petani dan ibunya sebagai ibu rumah tangga. Meski setidaksuka-sukanya kedua buah itu akan tetapi masih ada buah yang disukai seperti pisang emas dan mangga, karena itu mungkin tersedia di rumah.

Untuk porsi konsumsi buah, terjadi penurunan pada remaja yang memiliki porsi konsumsi buah yang kurang sebelum dan sesudah intervensi. Sebelum intervensi, remaja yang memiliki porsi konsumsi buah yang kurang yaitu 25,6\% kemudian sesudah intervensi menurun menjadi $23,3 \%$.

Berdasarkan hasil analisis dengan menggunakan uji McNemar menunjukkan tidak terdapat perbedaan porsi konsumsi buah remaja antara sebelum dan sesudah pemberian leaflet, di mana diperoleh nilai probabilitas $(p)=1,000(p>0,05)$, atau dengan perkataan lain tidak ada perbedaan secara signifikan antara porsi konsumsi buah remaja sebelum dan sesudah pemberian leaflet. Hal ini menunjukkan bahwa pemberian leaflet tidak mampu memengaruhi porsi konsumsi buah siswa.

Hasil penelitian sejalan dengan penelitian yang dilakukan oleh Saputra tentang pengaruh pemberian edukasi gizi melalui media video dan leaflet terhadap perubahan konsumsi buah dan sayur pada siswa SMP Al Chasanah yang menjelaskan bahwa tidak terdapat perbedaan konsumsi buah pada kelompok media video dan media leaflet sebelum edukasi yaitu nilai $\mathrm{p}=0.385$ $(\mathrm{p}>0.05)$ dan tidak terdapat perbedaan konsumsi sayur pada kelompok media video dan kelompok media leaflet sebelum edukasi yaitu nilai $\mathrm{p}=0.295(\mathrm{p}>0.05) .{ }^{12}$

Hasil penelitian tidak sejalan dengan penelitian yang dilakukan oleh Tampubolon tentang pengaruh media visual poster dan leaflet makanan sehat terhadap perilaku konsumsi makanan jajanan pelajar kelas khusus SMA Negeri 1 Panyabungan Kabupaten Mandailing Natal terbukti bahwa pemajangan poster dan pemberian leaflet dapat memengaruhi perilaku konsumsi makanan jajanan para pelajar tersebut. ${ }^{11}$

\section{KESIMPULAN}

Brdasarkan hasli penelitian dapat diketahui bahwa Edukasi gizi menggunakan leaflet Kemenkes ternyata mampu meningkatkan pengetahuan, sikap, dan pola konsumsi sayur dan buah siswa dengan peningkatan pengetahuan sebesar 10,8\%, sikap sebesar 1,2\%, konsumsi sayur sebesar 6,3\%, dan konsumsi buah sebesar 10,7\%, meskipun tidak meningkat secara signifikan. Diperlukan adanya tambahan edukasi gizi tentang konsumsi sayur dan buah pada remaja mengingat rekomendasi kecukupan konsumsi buah dan sayur yaitu sebanyak 400 gram per hari atau sebanyak 3-5 porsi sehari.

\section{DAFTAR PUSTAKA}

1. Khomsan A. Peranan Pangan dan Gizi untuk Kualitas Hidup. Yogyakarta: Grasindo; 2004. $188 \mathrm{p}$.

2. Na M. Hubungan Pola Konsumsi Buah dan Sayur dengan Morbiditas pada Siswa di Pondok Pesantren Ilmu Al-Qur'an di Kecamatan Ciomas, Kabupaten Bogor. Skripsi. Institut 
Pertanian Bogor; 2017.

3. World Health Organization. Fruit and Vegetable Promotion Initiative [Internet]. World Health Organization. Geneva; 2003. Available from: https://apps.who.int/iris/bitstream/handle/10665/68395/WHO_NMH_NPH_NNP_0308.pdf? sequence $=1 \&$ is Allowed $=\mathrm{y}$

4. Riset Kesehatan Dasar. Perilaku Konsumsi Sayur dan Buah [Internet]. 2013 [cited 2018 May 11]. Available from: http://www.depkes.go.id/resources/download/general/Hasil Riskesdas 2013.pdf

5. Achmad N, Hadju V, Salam A. Gambaran Pengetahuan, Sikap, Ketersediaan dan Pola Konsumsi Sayur dan Buah Remaja di Makassar. Skripsi. Universitas Hasanuddin; 2014.

6. Shekhawat S, P P G, Gupta M, Kakkar M, Mathur M, Ahaluwalia N, et al. Nutrition in adolescence - Issues and Challenges for the Health Sector : Issues in Adolescent Health and Development. J Evol Med Dent Sci. 2014;3(16):4299-309.

7. Rhan16. Penyakit Akibat Lalai Mengonsumsi Buah dan Sayur serta Solusi Penyembuhannya [Internet]. Berbagi itu Indah. 2009 [cited 2018 May 26]. Available from: https://rhan16.wordpress.com/2009/06/02/insight-5-penyakit-akibat-lalai-mengonsumsibuah-dan-sayur-serta-solusi-penyembuhannya/

8. Suhardjo. Sosio Budaya Gizi. Bogor: Departemen Pendidikan dan Kebudayaan, Direktorat Jenderal Pendidikan Tinggi; 2003. 217 p.

9. Lazzeri G, Pammolli A, Azzolini E, Simi R, Meoni V, De Wet DR, et al. Association between fruits and vegetables intake and frequency of breakfast and snacks consumption: A cross-sectional study. Nutr J [Internet]. 2013;12(1):1. Available from: https://www.ncbi.nlm.nih.gov/pmc/articles/PMC3765730/

10. Kapti RE, Rustina Y, Widyatuti. Efektifitas Audiovisual sebagai Media Penyuluhan Kesehatan terhadap Peningkatan Pengetahuan dan Sikap Ibu dalam Tatalaksana Balita dengan Diare di Dua Rumah Sakit Kota Malang. J Ilmu Keperawatan [Internet]. 2013;1(1):53-60. Available from: https://jik.ub.ac.id/index.php/jik/article/view/52/74

11. Tampubolon F. Pengaruh Media Visual Poster dan Leaflet Makanan Sehat terhadap Perilaku Konsumsi Makanan Jajanan Pelajar Kelas Khusus SMA Negeri 1 Panyabungan Kabupaten Mandailing Natal Tahun 2009. Skripsi. Universitas Sumatera Utara; 2009.

12. Saputra MD, Wahyuni Y, Nuzrina R. Pengaruh Pemberian Edukasi Gizi Melalui Media Video dan Leaflet terhadap Perubahan Konsumsi Buah dan Sayur pada Siswa SMP Al Chasanah Tahun 2016. 2016;1-16. Available from: https://digilib.esaunggul.ac.id/pengaruhpemberian-edukasi-gizi-melalui-media-video-dan-leaflet-terhadap-perubahan-konsumsibuah-dan-sayur-pada-siswa-smp-al-chasanah-tahun-2016-7570.html

13. Dahlan MS. Besar Sampel dan Cara Pengambilan Sampel dalam Penelitian Kedokteran dan Kesehatan. 3rd ed. Jakarta: Salemba Medika; 2010. 186 p.

14. Sugiyono. Metode Penelitian Pendidikan Pendekatan Kuantitatif, Kualitatif, dan R\&D. Cetakan 11. Bandung: Alfabeta; 2010.

15. Kementrian Kesehatan RI. Pedoman Gizi Seimbang [Internet]. Abdul BAK, Thaha AR, editors. Pedoman Gizi Seimbang. Jakarta: Direktur Jenderal Bina Gizi dan KIA; 2014. 1-90 
p. Available from: http://gizi.depkes.go.id/download/Pedoman Gizi/\%0APGS Ok.pdf\%0A

16. Dewantari NM, Widiani A. Fruits And Vegetables Consumption Pattern In School Children. J Skala Husada [Internet]. 2011;8(2):119-25. Available from: http://www.poltekkesdenpasar.ac.id/files/JSH/V8N2/Ni Made Dewantari1 dan Ari Widiani2 JSH V8N2.pdf

17. Indonesia PG. Ilmu Gizi: Teori \& Aplikasi. Cet. 2017. Hardinsyah, Supariasa IDN, editors. Jakarta: Penerbit Buku Kedokteran EGC; 2016. 621 p.

18. Notoatmodjo S. Ilmu Kesehatan Masyarakat. Jakarta: Rineka Cipta; 2003. 214 p.

19. Notoatmodjo S. Promosi Kesehatan dan Perilaku Kesehatan. Rev. 2012. Jakarta: Rineka Cipta; 2012. 260 p.

20. Azzahra MF, Muniroh L. Pengaruh Konseling terhadap Pengetahuan dan Sikap Pemberian MP-ASI. Media Gizi Indones [Internet]. 2015;10(1):20-5. Available from: https:/ejournal.unair.ac.id/MGI/article/view/3121/0

21. Dakhi T. Pengaruh Pemberian Pendidikan Gizi Melalui Media Leaflet tentang Sayur dan Buah terhadap Pengetahuan, Sikap, dan Praktik Ibu Murid SDN 105349 Paluh Kemiri dalam Menyediakan Sayur dan Buah untuk Keluarga [Internet]. Repository Poltekkes Kemenkes Medan. Politeknik Kesehatan Kemenkes Medan; 2018. Available from: http://poltekkes.aplikasi-akademik.com/xmlui/handle/123456789/1083 